\title{
ASPEK HUKUM SUBJEK PAJAK BENTUK USAHA TETAP MENURUT HUKUM POSITIF DI INDONESIA
}

\author{
Paulus Aluk Fajar Dwi Santo \\ Jurusan Manajemen, Fakultas Ekonomi dan Bisnis, Universitas Bina Nusantara \\ Jln. K.H. Syahdan No. 9, Palmerah, Jakarta Barat 11480 \\ Paulus_afds@binus.edu
}

\begin{abstract}
PE (Permanent Establishment) is an international tax terminology which is a consequence of the operations of the base/fixed sites in the treaty partner country, after fulfilling certain conditions stipulated in the Tax Treaty or the Act, such as: types of business activities conducted in the country treaty partner, source of income and the term ("Time Test"). The existence of permanent establishments of this affect a country's right to impose a tax on the object is meant. Status BUT in practice still needs to be studied again, the research method used is a historical-juridical, comparatif and analytical as well as using interview techniques. Travel Tax Act in determining the status BUT we found frequent changes eg, in the 1925 Corporate Tax BUT as the subject of placing a foreign tax, then Law No. 7 / 1983 BUT put as the subject of domestic taxes and the Law No. 10 years in 1994 stutus BUT reinstated as foreign tax subject until now. There are also difficulties associated with determining the condition of BUT for certain conditions eg how to define a PE for a transaction that uses E-Commerce. It would need to be reviewed relates to the status of PE as a tax subject and also have already started to set up regulations relating to the determination of a PE are complete.
\end{abstract}

Keywords: permanent establishment, tax treaty, e-Commerce

\begin{abstract}
ABSTRAK
BUT (Permanent Establishment) merupakan terminologi perpajakan internasional yang merupakan konsekuensi dari kegiatan usaha dengan basis/lokasi tetap di negara treaty partner, setelah memenuhi kondisi-kondisi tertentu yang diatur dalam Tax Treaty atau Undang-undang, seperti: jenis kegiatan usaha yang dilaksanakan di negara treaty partner, sumber penghasilan dan jangka waktu ("Time Test"). Adanya Bentuk Usaha Tetap ini mempengaruhi Hak suatu negara untuk mengenakan pajak terhadap obyek yang di maksud. Status BUT dalam praktek masih perlu dikaji lagi, metode penelitian yang digunakan adalah secara historis-yuridis, comparatif dan analitis serta mengunakan tekhnik wawancara. Perjalanan UU Pajak kita dalam menentukan status BUT ternyata sering berubah-ubah misal, dalam Pajak Perseroan 1925 menempatkan BUT sebagai subjek pajak luar negeri, kemudian Undang-undang No. 7 Tahun 1983 menempatkan BUT sebagai subjek pajak dalam negeri kemudian Undang-undang No. 10 tahun 1994 stutus BUT dikembalikan lagi sebagai Subjek pajak luar negeri sampai dengan sekarang. Ada kesulitan juga berkaitan dengan penentuan kondisi BUT untuk kondisi-kondisi tertentu suatu missal bagaimana menentukan suatu BUT untuk transaksi yang menggunakan E-Commerce. Kiranya perlu dikaji ulang berkaitan dengan status BUT sebagai Subjek Pajak dan juga harus sudah mulai disiapkan peraturan yang terkait dengan penentuan suatu BUT secara lengkap.
\end{abstract}

Kata kunci: permanent establishment , tax treaty, e-Commerce 


\section{PENDAHULUAN}

Seiring dengan perkembangan yang pesat di bidang transaksi internasional yang meliputi perdagangan, jasa, dan modal, maka pajak menjadi masalah/isu klasik, misalnya negara mana yang berhak memajaki penghasilan yang timbul dari transaksi internasional, transfer pricing, penyelundupan dan penggelapan pajak, dan lain-lain. Kiranya untuk mencegah masalah perpajakan yang timbul dari transaksi internasional itu diperlukan kerjasama di antara negara-negara dan salah satu bentuk kerjasama tersebut adalah perjanjian bilateral di bidang perpajakan, yang dikenal dengan Perjanjian penghindaran pajak berganda (Tax Treaty).

Tax Treaty berisikan ketentuan yang mengatur mengenai pembagian hak pemajakan dari masing-masing negara atas penghasilan yang timbul dari transaksi internasional sehingga pengenaan pajak berganda dapat dihindari. Selain itu, tax treaty mengatur mengenai pertukaran informasi yang dibutuhkan untuk mencegah timbulnya penyelundupan pajak melalui praktek-praktek transfer pricing.

Berkaitan dengan Tax Treaty kemudian muncullah suatu model subjek pajak baru yang sering kita kenal dengan istilah Bentuk Usaha Tetap. Bentuk Usaha Tetap sekarang ini sudah menjadi terminologi baku dalam ketentuan Pajak Internasional. Adanya Bentuk Usaha Tetap ini mempengaruhi Hak suatu negara untuk mengenakan pajak terhadap obyek yang di maksud. Dalam prakteknya, di negara Indonesia ternyata konsistensi secara hukum berkaitan dengan status personil bentuk usaha tetap yang diperlakukan sebagai subjek pajak luar negeri ini masih perlu kita kaji lagi. Kenyataan di atas kita lihat di dalam perjalanan UU Pajak kita dalam menentukan status BUT, Dalam Undangundang No. 8 Tahun 1967 tentang perubahan dan penyempurnaan Pajak Pendapatan 1944, Pajak Kekayaan 1932, Pajak Perseroan 1925 menempatkan BUT sebagai subjek pajak luar negeri, kemudian Undang-undang No. 7 Tahun 1983 dalam pasal 2 ayat 3 (c) menempatkan BUT sebagai subjek pajak dalam negeri, di dalamnya menyebutkan: yang menjadi subjek pajak dalam negeri adalah sebagai berikut

\footnotetext{
"Bentuk usaha tetap yaitu bentuk usaha yang dipergunakan untuk menjalankan kegiatan usaha secara teratur di Indonesia, oleh badan atau perusahaan yang tidak didirikan atau tidak bertempat kedudukan di Indonesia, yang dapat berupa tempat kedudukan manajemen, kantor cabang, kantor perwakilan, agen, gedung kantor, pabrik, bengkel, proyek kontruksi, pertambangan dan penggalian sumber alam, perikanan, tenaga ahli, pemberian jasa dalam bentuk apapun oleh pegawai, atau oleh orang lain atau badan yang berkedudukan tidak bebas yang bertindak atas nama badan tau perusahaan yang tidak didirikan atau tidak berkedudukan di Indonesia dan perusahaan asuransi yang tidak didirikan atau tidak bertempat kedudukan di Indonesia yang menerima premi asuransi atau menanggung resiko di Indonesia”.
}

Berikutnya, sejak dikeluarkannya Undang-undang No.10 Tahun 1998, status BUT dikembalikan kepada dasar legalitasnya (back to basic) sebagai kepanjangan tangan dan sarana memperoleh penghasilan usaha dari perusahan Wajib Pajak Luar Negeri.

Menjadi lebih menarik lagi, ternyata pemakaian istilah Bentuk Usaha Tetap ini sudah tidak menjadi monopoli bidang perpajakan, seperi yang kita ketahui dalam UU Migas, salah satu badan usaha yang diijinkan melakukan kontrak kerja di sektor Migas adalah Bentuk Usaha Tetap. Lebih jauh lagi, ternyata ada juga suatu Keputusan Gubernur Propinsi Daerah Khusus Ibukota Jakarta No. 57 Tahun 2001 tentang Pembentukan Komisi Penilai Analisis mengenai Dampak Lingkungan Propinsi Khusus Daerah Ibukota Jakarta Bab I Pasal 1 ayat (18), yang berbunyi: "Badan Hukum adalah suatu bentuk badan hukum yang meliputi Perseroan Terbatas, Perseroan Komanditer, dan Perseroan lainnya dengan nama dan bentuk apapun, persekutuan, perkumpulan, firma, koperasi, yayasan atau organisasi yang sejenis, lembaga dana pensiun, bentuk usaha tetap serta bentuk usaha lainnya”. 
Terakhir lebih rumit lagi berkaitan dengan maraknya aktifitas E’ Commerce yang transaksi perdagangnya mengunakan media Internet, dimana perusahaan perusahaan yang di dirikan dan berdomisili di luar negara Indonesia, namun memperoleh keuntungan dari negara Indonesia dengan cara E' Commerce. Hal ini masih menjadi polemik, apakah bisa dikategorikan dalam Bentuk Usaha Tetap.

Maka berkaitan dengan permasalahan-permasalahan yang ada di atas, penulis tertarik mengkaji aspek hukum dari Bentuk Usaha Tetap ini secara konstruktif berdasarkan kerangka pemikiran akademis.

Setiap negara mempunyai undang-undang pajak yang berbeda dalam hal menentukan hak pemajakan internasionalnya. Artinya, setiap negara unilateral menentukan sendiri jursdiksi perpajakan internasionalnya, baik yang menyangkut objek pajak maupun subjeknya. Hal ini memungkinkan terjadinya pengenaan pajak berganda bila dua jurisdiksi pajak berinteraksi sebagai akibat terjadinya transaksi antara dua negara tersebut. Setiap negara mempunyai metode penghindaran pajak berganda, namun demikian hal ini tidak menjamin bahwa pengenaan pajak berganda dapat di hindarkan sepenuhnya.

Di sinilah letak pentingnya suatu persetujuan penghindaran pajak berganda antara dua negara. Persetujuan ini melalui suatu proses kompromi yang panjang, tergantung pada sejauh mana suatu negara menentukan hak pemajakan internasionalnya. Pada dasarnya, suatu persetujuan penghindaran pajak berganda adalah penghindaran pajak secara juridis. Pasal-pasal yang ada di dalam persetujuan tersebut pada hakikatnya adalah distributive rules, yaitu membagi hak pemajakan dua negara. Penghasilan dari usaha sebuah perusahaan yang berdomisili di suatu negara hanya akan dikenai pajak di negara tersebut, kecuali usaha tersebut dilakukan di negara sumber melalui permanent establishment/Bentuk Usaha Tetap (sesuai definisi berdasarkan P3B). Mengingat bahwa penelitian ini memfokuskan pada aspek hukum Bentuk Usaha Tetap, maka yang menjadi permasalahan dalam penelitian ini adalah: bagaimana ketentuan yuridis terkait dengan terdapatnya suatu bentuk usaha tetap sebagai subjek pajak di suatu negara, dan kesulitan apa saja yang terkait dengan pengenaan pajak untuk bentuk usaha tetap tertentu.

Maksud dan tujuan penelitian adalah untuk mencoba mencari pendekatan secara yuridis perjanjian-perjanjian peghindaran pajak ganda yang telah dilakukan Indonesia dengan negara asing dan hubungannya dengan Undang-undang Perpajakan Nasional kita. Sasaran akhirnya adalah mencari pendekatan secara yuridis berkaitan dengan bentuk usaha tetap sebagai subjek pajak luar negeri dengan segala aspek hukumnya yang timbul maupun yang mungkin akan timbul, lebih lanjut akan mengkaji konsistensi hak dan kewajiban perpajakan dari suatu Bentuk Usaha Tetap.

Kegunaan penelitian ini dapat dilihat baik dari segi teoritis maupun dari segi praktis, yang oleh penulis akan dirumuskan sebagi berikut. Secara teoritis penelitian ini nantinya di harapkan akan bermanfaat dalam perkembangan ilmu hukum pajak di Indonesia dan pelaksanaan-pelaksanaan perjanjian perpajakan yang akan diadakan denga negara asing. Secara praktis, diharapkan hasil penelitian ini di kemudian hari akan berguna dalam menentukan kebijaksanaan dalam pelaksanaan undang-undang pajak di Indonesia, yang menyangkut subjek pajak luar negeri, terutama yang menyangkut Bentuk Usaha Tetap dengan segala aspek hukum serta segala aspek pemajakannya.

\section{METODE PENELITIAN}

Di dalam pelaksanaan penelitian ini akan digunakan metode penelitian historis-yuridis, metode comparatif dan metode penelitian analitis serta menggunakan teknik wawancara. Secara 
histories-comparatif, akan dikumpulkan bahan-bahan dari kepustakaan, maupun dokumen-dokumen yang berhubungan dengan perjanjian perpajakan pada umumnya dan Bentuk Usaha Tetap secara khusus. Dari literatur serta dokumen-dokumen yang ada akan ditemukan fakta-fakta yang berkaitan dengan latar belakang penulisan karya ilmiah ini, selanjutnya diadakan perbandingan-perbandingan fakta yang ditemukan maupun teori-teori hukum yang ada sehingga merupakan suatu metode historisyuridis dan historis-comparatif. Wawancara/interview diadakan setelah didapat gambaran pertama tentang latar belakang dan ditemukannya masalah-masalah dari obyek yang ditinjau.

Akhirnya data-data yang diperoleh berupa keterangan maupun dokumen-dokumen pelaksanaan yang dipraktekkan dianalisa secara yuridis, hasil analisa yuridis ini dituangkan dalam tulisan atau makalah ini.

\section{HASIL DAN PEMBAHASAN}

\section{Ketentuan Yuridis Terkait dengan Terdapatnya Suatu Bentuk Usaha Tetap sebagai Subjek Pajak di Suatu Negara.}

Ketentuan mengenai Bentuk Usaha Tetap dalam suatu Perjanjian Perpajakan sangat penting artinya. Ketentuan mengenai bentuk usaha tersebut, selain mengatur mengenai hak negara sumber untuk mengenakan pajak atas laba usaha (business profits) yang diterima atau diperoleh perusahaan yang berkedudukan di negara mitranya, juga mengatur mengenai cara pemajakan laba usaha. Berdasarkan ketentuan Perjanjian Perpajakan, negara sumber dapat mengenakan pajak atas laba usaha yang diterima atau diperoleh perusahaan yang berkedudukan di negara mitranya hanya apabila perusahaan tersebut melakukan kegiatan atau usaha melalui bentuk usaha yang ada di negara sumber.

Dengan demikian, pengertian bentuk usaha tetap sangatlah penting artinya karena pengertian tersebut dipakai sebagai ukuran untuk menentukan ada tidaknya bentuk usaha tetap di suatu negara, yang pada gilirannya menentukan berhak tidaknya negara yang bersangkutan mengenakan pajak atas laba usaha yang diperoleh atau diterima dari negara itu oleh perusahaan yang berkedudukan di negara mitranya. Pengertian bentuk usaha tetap di dalam Perjanjian Perpajakan, tergantung kepada pengertian yang diberikan oleh masing-masing Perjanjian Perpajakan yang bersangkutan yang dapat berbeda dari satu perjanjian perpajakan ke perjanjian perpajakan lainnya. Pada umumnya, dalam perjanjian perpajakan bentuk usaha tetap (permanent establishment) diartikan sebagai suatu tempat tertentu di mana seluruh atau sebagian usaha perusahaan (luar negeri) dijalankan. Dari rumusan tersebut di atas, untuk adanya suatu bentuk usaha tetap diperlukan adanya dua kondisi, yaitu adanya suatu tempat usaha tertentu, dan di tempat usaha tertentu tersebut kegiatan usaha (business activities) dari suatu perusahaan (luar negeri) dijalankan, baik sebagian atau seluruhnya.

Pengertian BUT dalam Undang-undang Pajak Penghasilan No. 36 Tahun 2008 terdapat dalam pasal 2 ayat (5), yang memberi rumusan tentang apa yang dimaksud dengan bentuk usaha tetap, yaitu bentuk usaha yang dipergunakan oleh orang pribadi yang tidak bertempat tinggal di Indonesia, orang pribadi yang berada di Indonesia tidak lebih dari seratus delapan puluh tiga hari dalam jangka waktu dua belas bulan, dan badan yang tidak didirikan dan tidak bertempat kedudukan di Indonesia untuk menjalankan usaha atau melakukan kegiatan di Indonesia, yang dapat berupa tempat kedudukan management, cabang perusahaan, kantor perwakilan, gedung kantor, pabrik, bengkel, gudang, ruang untuk promosi dan penjualan, pertambangan dan penggalian sumber alam, wilayah kerja pertambangan minyak dan gas bumi, perikanan, peternakan, pertanian, perkebunan,atau kehutanan, proyek konstruksi, instalasi, atau proyek perakitan, pemberian jasa dalam bentuk apa pun oleh pegawai atau orang lain, sepanjang dilakukan lebih dari enam puluh hari dalam jangka waktu dua belas bulan, orang atau badan yang bertindak selaku agen yang kedudukannya tidak bebas, agen atau 
pegawai dari perusahan asuransi yang tidak didirikan dan tidak bertempat kedudukan di Indonesia yang menerima premi asuransi atau menanggung risiko di Indonesia, dan komputer, agen elektronik, atau peralatan otomatis yang dimiliki, disewa, atau digunakan oleh penyelenggara transaksi elektronik untuk menjalankan usaha melalui internet.

Pengertian Bentuk Usaha Tetap berdasarkan Kelaziman Internasional (UN Model dan OECD Model). Pasal yang mengatur bentuk usaha tetap berdasarkan UN Model tersebut adalah seperti diuraikan di bawah ini.

\section{Article 5}

Permanent establishment for the purposes of this Convention, the term "permanent establishment" means a fixed place of business through which the business of an enterprise is wholly or partly carried on.

Pengertian "bentuk usaha tetap" ini diberikan sebagai salah satu cara untuk menghindari pengenaan pajak berganda atas laba usaha, yaitu penentuan negara mana yang berhak mengenakan pajak atas laba usaha (business income) sebagaimana diatur dalam pasal 7.

Ayat 1 dari pasal ini sama dengan rumusan yang dipakai oleh OECD dan mempunyai pengertian bahwa suatu bentuk usaha tetap bersifat tetap dengan situasi tertentu. Definisi tersebut mengandung beberapa syarat, yaitu adanya tempat usaha berupa prasarana, seperti gedung atau dalam hal-hal tertentu mesin dan peralatan; tempat usaha ini harus bersifat tetap; dan kegiatan usaha perusahaan tersebut dilakukan melalui tempat tetap ini. Karakteristik lain dari suatu bentuk usaha tetap adalah bahwa sifatnya produktif, artinya ia turut memberikan andil dalam memperoleh laba usaha bagi perusahaannya (kantor pusatnya).

Pengertian "tempat untuk menjalankan usaha" mencakup gedung-gedung, prasarana atau instalasi yang digunakan untuk menjalankan usaha, tanpa melihat apakah penggunaannya semata-mata untuk tujuan tersebut. Tempat untuk menjalankan usaha ini juga dianggap ada walaupun tanpa prasarana gedung, karena satu ruangan tertentu adalah sudah cukup untuk disebut sebagai tempat untuk menjalankan usaha. Jadi tidak relevan apakah prasarana tersebut milik perusahaan atau disewa dari perusahaan lain. Karena itu, tempat menjalankan usaha ini mencakup satu ruangan kecil di sebuah pasar atau satu tempat di daerah kantor bea cukai. Yang penting adalah perusahaan tersebut mempunyai hak untuk menggunakan satu tempat atau ruangan untuk menjalankan usahanya.

Berdasarkan definisi, tempat untuk menjalankan usaha harus bersifat "tetap”. Jadi, biasanya ada kaitan antara tempat tersebut dan titik geografis. Dengan demikian, suatu peralatan yang digunakan untuk menjalankan usaha, misalnya dapat dianggap berada di sebuah "tempat tetap" walaupun tidak tertanam di tanah. Keberadaannya di satu lokasi sudah cukup untuk dianggap berada di satu "tempat tetap." Karena tempat untuk usaha ini sifatnya tetap, maka tempat tersebut harus dipersiapkan sedemikian rupa agar bertahan lama. Namun, bila tempat tetap ini kemudian ditinggalkan karena alasan-alasan tertentu, misalnya wajib pajak yang bersangkutan meninggal atau karena investasi yang salah urus, tempat tersebut tetap dianggap sebagai bentuk usaha tetap, walaupun ia tidak langsung untuk jangka waktu yang panjang.

Baik harta berwujud seperti peralatan, prasarana, atau gedung, maupun tidak berwujud seperti hak paten, atau hak-hak lainnya yang disewakan kepada pihak ketiga melalui satu tempat tetap yang digunakan oleh satu perusahaan yang berkedudukan di negara lain dianggap sebagai bentuk usaha tetap. Bila penyewaan harta-harta tersebut tidak melalui satu tempat tetap, hal itu tidak menimbulkan bentuk usaha tetap karena kegiatannya semata-mata hanya menyewakan peralatan. Hal yang sama juga berlaku jika perusahaan tersebut mengirim orang untuk mengoperasikan peralatan, dengan catatan bahwa orang ini hanya bertanggung jawab atas pengoperasian peralatan berdasarkan pengarahan dari penyewa. Seandainya orang tersebut mempunyai tanggung jawab yang lebih besar, misalnya ikut 
memutuskan jenis pekerjaan yang akan menggunakan peralatan itu, perusahaan pemilik peralatan tersebut sudah melampaui kedudukannya sebagai yang menyewakan (lessor). Dalam hal ini, bentuk usaha tetap dianggap ada jika kriteria "tetap" dipenuhi. Apabila kegiatan tersebut dikaitkan dengan ayat 3 (proyek konstruksi, instalasi atau pemberian jasa), tes waktu sesuai dengan P3B yang bersangkutan akan ditetapkan.

Kegiatan usaha dari sebuah perusahaan yang berkedudukan di satu negara dan dilakukan di negara lain dapat dilaksanakan oleh personel yang digaji dalam hubungan kerja. Personel tersebut mungkin karyawan sendiri atau orang lain yang menerima instruksi dari perusahaan tersebut, dan mereka bisa disebut dependent agent. Berhak mereka menandatangani atas nama perusahaan adalah tidak relevan; yang penting adalah mereka menerima instruksi dari kantor pusatnya.

Bentuk usaha tetap dianggap mulai timbul pada saat sebuah perusahaan mulai melakukan kegiatan usahanya melalui tempat yang tetap. Hal ini dapat diketahui pada saat perusahaan mempersiapkan tempat yang dimaksud sebagai tempatnya yang tetap. Masa persiapan tempat tersebut tidak perlu dihitung sepanjang kegiatan tersebut berbeda sama sekali dari kegiatan perusahaan yang kan dilaksanakan melalui tempat itu. Suatu bentuk usaha tetap akan dianggap tidak ada lagi bila tempat itu. Suatu bentuk usaha tetap akan dianggap tidak ada lagi bila tempat itu tidak dipakai lagi bila tempat itu tidak dipakai lagi atau pada saat kegiatan usahanya tidak di lanjutkan, dan bila semua kegiatan yang berkaitan dengan kegiatan bentuk usaha tetap sebelumnya dihentikan. Namun, penghentian sementara kegiatan tidak berarti keberadaan suatu bentuk usaha tetap berhenti.

The term "permanent establishment" includes especially: tempat kedudukan manajemen, cabang, kantor, pabrik, bengkel, lokasi pertambangan, sumur minyak atau gas, lokasi penggalian atau penambangan sumber alam lainnya. Pengertian ini mencakup bangunan, konstruksi, proyek perakitan atau kegiatan pengawasan yang ada hubungannya dengan proyek tersebut, asalkan bangunan dan konstruksi serta kegiatan pengawasannya berlangsung selama lebih dari jangka waktu tertentu, pemberian jasa, termasuk jasa konsultan yang diberikan oleh suatu perusahaan melalui karyawannya atau orang lain yang dipekerjakan oleh perusahaan untuk keperluan tersebut, sepanjang kegiatan itu berlangsung untuk proyek yang sama, atau yang berkaitan, di negara tersebut selama jangka waktu tertentu dalam kurun waktu dua belas bulan.

Tampak bahwa proyek konstruksi dan pemberian jasa tersebut memerlukan tes waktu agar kegiatan tersebut dianggap sebagai bentuk usaha tetap. Penentuan jangka waktu tersebut tergantung pada undang-undang masing-masing negara dan pada seberapa jauh keduanya keduanya bersedia berkompromi. Bagi negara-negara yang sedang berkembang, semakin singkat tes waktu untuk kedua hal tersebut adalah semakin baik, karena kesempatan mengenakan pajak atas kegiatan tersebut semakin besar. Negara-negara maju menginginkan agar tes waktu ini ditetapkan cukup panjang misalnya 12 bulan, karena mereka berpendapat bahwa laba usaha dari kegiatan ini seharusnya dikenakan di negara domisili. Sebaliknya, negara-negara berkembang lebih menyukai tanpa tes waktu sehingga pajak dapat dikenakan sejak hari pertama hadirnya proyek tersebut.

Tes waktu proyek konstruksi dan pemberian jasa dalam P3B yang sudah berlaku (P3B Indonesia dengan negara-negara lain) tersebut bervariasi, bisa 120 hari, tiga bulan atau enam bulan. Jika perjanjian menyebutkan bahwa tes waktunya adalah enam bulan, dan jika kegiatan konstruksi tersebut berlangsung lebih dari enam bulan, maka perusahaan tersebut dianggap mempunyai bentuk usaha tetap di negara sumber. dengan demikian, negara sumber berhak mengenakan pajak terhadap perusahaan yang berasal dari negara domisili. Proyek konstruksi atau instalasi juga mencakup proyek pembangunan jalan, jembatan, terowongan, pemasangan pipa-pipa, penggalian dan pengerukan.

Perhitungan tes waktu tersebut dimulai pada saat kontraktor mempersiapkan dan memulai pekerjaannya di negara tempat dilaksanakan pembangunan itu. Pekerjaan persiapan ini termasuk mendirikan bangunan untuk keperluan perencanaan dan kegiatan konstruksi tersebut. Proyek tersebut 
dianggap terus berlangsung sampai pekerjaan selesai atau ditinggalkan untuk seterusnya. Proyek tersebut tidak dianggap berhenti ketika pekerjaan tersebut dihentikan untuk sementara. Karena itu, penghitungan masa 6 bulan, misalnya, adalah termasuk masa selama pekerjaan berhenti untuk sementara. Penghentian sementara ini bisa disebabkan oleh kurangnya bahan bangunan, kesulitan buruh, atau cuaca yang jelek.

Apabila seorang kontaktor utama membagi sebagian pekerjaannya kepada subkontraktor, masa yang digunakan oleh subkontraktor dalam melaksanakan pekerjaannya harus dihitung sebagai masa yang digunakan oleh kontraktor utama. Sedangkan subkontraktor itu sendiri akan dianggap mempunyai bentuk usaha tetap apabila pekerjaannya melebihi 6 bulan. Jika sebuah perusahaan dari negara domisili melakukan kegiatan konstruksi atas lebih dari satu proyek di negara sumber, maka setiap proyek harus dihitung sendiri-sendiri untuk menentukan apakah kegiatan tersebut menimbulkan bentuk usaha tetap. Artinya, penghitungan waktunya harus terpisah. hal ini dilakukan apabila kedua proyek tersebut merupakan proyek yang terpisah.

Terdapat perbedaan pandangan antara negara berkembang dan negara maju mengenai masalah tes waktu dalam hal proyek konstruksi ini. Negara-negara berkembang cenderung untuk tidak menerapkan tes waktu sama sekali dengan alasan: proyek konstruksi, instalasi, dan perakitan merupakan hasil teknologi yang canggih, sehingga dalam waktu yang relatif singkat dapat diselesaikan dengan penghasilan yang cukup tinggi, masa selama hadirnya personel dari perusahaan asing tersebut adalah tidak relevan dengan penyelesaian proyek tersebut, dan dengan ditetapkannya tes waktu maka perusahaan yang berasal dari negara-negara maju (sebagai capital exporting country) didorong untuk melakukan penyelundupan pajak (tax evasion).

Pandangan ini didasarkan atas pemikiran bahwa sebenarnya tidak perlu pembedaan perlakuan antara proyek konstruksi dan para artis atau atlet profesional karena mereka dikenai pajak di negara di mana kegiatannya dilakukan tanpa mempedulikan berapa lama kegiatan tersebut dilakukan.

Perencanaan dan pengawasan atas pembangunan gedung atau kontruksi lainnya merupakan bagian dari proyek sepanjang dilakukan oleh kontaktor utama yang sama. Apabila perencanaan dan pengawasan tersebut dilakukan oleh perusahaan lain, perlakuan yang diberikan akan terpisah dari kontraktor utama. Jika perusahaan yang melakukan perencanaan dan pengawasan tersebut menjalankan kegiatannya melalui kantor yang berada di lokasi proyek dan semata-mata merancang serta mengawasi, tempat tersebut bukan bentuk usaha tetap karena sifatnya tidak tetap.

Contoh berikut ini merupakan bahan dari Workshop OECD tahun 1977 di Paris dan menarik untuk disimak. Build Ltd, adalah sebuah perusahaan yang berdomisili di negara A dan memperoleh kontrak membangun instalasi listrik di negara B. Pembangunan akan memakan waktu 4 tahun. Dalam melaksanakan pekerjaan tersebut, Build Ltd menunjuk beberapa subkontraktor untuk mengerjakan beberapa jenis pekerjaan. Buildlabour International Ltd. adalah perusahaan yang menyediakan tenaga kerja bagi Build Ltd. untuk melaksanakan pekerjaan itu di negara di negara B. Buildlabour International Ltd. adalah perusahaan yang berdomisili di A. Di samping itu, Build Ltd. juga menandatangani kontrak dengan Buildlease Ltd. yang menyewakan alat-alat yang digunakan dalam proyek tersebut. Buildlease Ltd. adalah juga penduduk negara A.

Dalam rangka pelaksanaan pengawasan atas proyek, Build Ltd. menandatangani kontrak dengan Build-management Ltd, yang bertugas melakukan pengawasan atas pelaksanaan pekerjaan konstruksi tersebut sampai selesai. Build Ltd. juga mensubkontrakkan pekerjaan-pekerjaan persiapan (preparation work) kepada Ground works Ltd. Berkaitan dengan interpretasi dari P3B, timbul pertanyaan bagaimana perlakuan pajak negara B atas perusahaan-perusahaan yang terlibat dalam proyek tersebut. 
Build Ltd. pasti akan dianggap mempunyai BUT di B sebab proyek tersebut memakan waktu 4 tahun. B adalah negara yang berlokasi di Eropa dan mempunyai empat musim, dan biasanya semua proyek akan berhenti selama musim dingin. Untuk penghitungan lamanya proyek, pekerjaan yang dihentikan karena musim dingin sama sekali diabaikan. Dengan kata lain, walaupun pekerjaan dihentikan untuk sementara selama musim dingin, penghitungan untuk menentukan apakah ia melewati tes waktu tetap berjalan. Dan mengingat proyek tersebut memakan waktu 4 tahun Build Ltd akan dianggap mempunyai BUT di B.

Buildlabour Ltd. adalah perusahaan yang menyediakan buruh atau staf yang melaksanakan konstruksi tersebut. Perusahaan ini tidak dianggap mempunyai BUT untuk proyek tersebut. Karyawan dan buruhnya telah dikontrak oleh Build Ltd. sehingga yang menjadi majikan adalah Build Ltd. Yang menjadi masalah di sini adalah hanya perlakuan pajak atas gaji yang diterima oleh karyawan yang dikontrak oleh Build Ltd, dan hal ini diatur dalam pasal 15 dari Model P3B.

Buildlease Ltd. yang menyewakan peralatan untuk proyek tersebut tidak akan dianggap mempunyai BUT di B sebab ia hanya menyewakan alat. Perlakuan pajak atas sewa tergantung pada definisi royalti yang diatur dalam Pasal 12. Menurut definisi dalam OECD Model, penyewaan alat-alat komersial dan industri tidak termasuk dalam pengertian "royalti" sehingga akan dikenai pajak di negara domisili yang dalam hal ini adalah A. Namun, bila definisi royalti tersebut mencakup penyewaan alat-alat, imbalan tersebut dapat dikenakan di B. Apapun perlakuan dari sewa tersebut (tergantung pada rumusan P3B antara A dan B di tangan Build Ltd., sewa tersebut dapat dikurangi sebagai biaya.

Perlakuan pajak terhadap Buildmanagement Ltd., yaitu perusahaan yang melakukan pengawasan atas pelaksanaan pekerjaan konstruksi, tergantung pada rumusan Pasal 5 ayat 3 (b). Sebagaimana perumusan yang disebutkan di atas, definisi BUT mencakup supervisory works. Dengan demikian, Buildmanagement Ltd. dianggap mempunyai BUT di B sebab jangka waktunya lebih dari yang disebutkan dalam P3B antara A dan B. Perlu disimak bahwa dalam OECD Model, rumusan Pasal 5 ayat 3 (b) tidak meliputi supervisory works. Jadi, seandainya P3B antara A dan B mengikuti OECD Model, Buildmanagement Ltd. tidak dapat dikenai pajak di B.

Pengenaan pajak oleh B terhadap Groundworks Ltd tergantung pada jangka waktu pekerjaan tersebut. Apabila melebihi tes waktu P3B antara A dan B, Groundworks Ltd, akan dianggap mempunyai BUT di B. Sebaliknya, apabila pelaksanaan pekerjaan tersebut kurang dari tes waktu, B tidak dapat mengenakan pajak terhadap Groundworks Ltd.

Ayat (3) huruf b merupakan ayat baru yang menyangkut definisi bentuk usaha tetap, yaitu pemberian jasa di luar jasa supervisi atas proyek bangunan. Model OECD tidak mempunyai ayat ini karena hal ini tidak sesuai dengan prinsip yang dianut, yaitu bahwa pemberian jasa teknik tersebut dikenakan di negara domisili.

Pemberian jasa yang diberikan oleh penduduk dari negara domisili hanya akan dikenai pajak di negara sumber dan melewati tes waktu sebagaimana diatur dalam P3B yang bersangkutan. Ini berarti bahwa apabila jasa tersebut dilakukan di negara sumber untuk masa kurang dari tes waktu seperti yang disebutkan dalam P3B yang bersangkutan imbalan dari pemberian jasa tersebut tidak dikenai pajak di negara sumber sebab kegiatan ini tidak menimbulkan bentuk usaha tetap. Hal yang sama juga berlaku apabila jasa tersebut dilakukan di negara domisili, yang tidak memenuhi ketentuan Pasal 5 ayat (3) huruf b. Pemberian jasa teknik dan konsultasi ini adakalanya dikenai pajak di negara sumber bukan melaui suatu bentuk usaha tetap, tetapi dengan cara yang lazim disebut "gross method", yaitu pemotongan (withholding). Dengan demikian, apabila penduduk dari negara domisili memberikan jasa teknik atau konsultasi di negara di negara sumber, imbalannya dikenai pemotongan oleh penduduk negara sumber yang membayarnya. Jadi, pengenaannya tidak melihat berapa lama kegiatan ini dilakukan. 
Jangka waktu penghitungan tes waktu untuk pemberian jasa berbeda dari penghitungan untuk proyek konstruksi. Dalam hal pemberian jasa, penghitungan waktunya tidak harus secara terusmenerus. Itulah sebabnya rumusannya menyebut “...months within any twelve month period..." Ini artinya adalah bahwa tes waktunya dihitung mulai hari pertama, kemudian dari sana dilihat dalam rentang waktu 12 bulan. Jika selama itu pemberian jasanya melebihi tesnya, ia akan dianggap sebagai bentuk usaha tetap. Pemberian jasa tersebut seringkali tidak diberikan secara terus-menerus.

Pemberian jasa oleh penduduk negara domisili biasanya dilakukan dengan mengirimkan tenaga ahlinya ke negara sumber. Jika dalam kurun waktu yang sama dikirim lebih dari satu orang, perhitungan waktu jumlahnya tenaga ahli tersebut tidak berpengaruh. Artinya, bila dalam taraf pertama jasa teknik ini diberikan selama satu bulan oleh dua orang tenaga ahli, penghitungan waktunya adalah tetap satu bulan.

Beberapa P3B adakalanya menambahkan “...for the same or connected project...” setelah time tes. Ini berarti bahwa penghitungan waktu untuk menentukan apakah pemberian jasa ini menimbulkan bentuk usaha tetap adalah berdasarkan setiap proyek. Misalnya, company X di negara A memberikan jasa di negara $\mathrm{B}$ kepada company $\mathrm{P}$ dan $\mathrm{N}$ adalah secara terpisah sepanjang keduanya tidak berhubungan.

Perlakuan ini sebenarnya berasal dari negara-negara maju agar tidak timbul kerancuan. Dari segi administrasi, hal ini sebenarnya lebih bagus karena pengawasannya dapat dilakukan dengan lebih baik. Namun dari segi penerimaan pajak, hal ini akan merugikan negara berkembang.

Per definisi yang sudah dikemukakan, sebenarnya tidak dapat bila bentuk usaha tetap dikategorikan sebagai subjek pajak. Dilihat dari pengertian subjek pajak yang umum, yang merupakan subjek pajak biasanya adalah orang pribadi atau badan hukum (misalnya PT, yayasan dan koperasi). Sebaliknya, bentuk usaha tetap pada umumnya berupa barang, misalnya pabrik, gedung kantor, bengkel, perkebunan, atau kegiatan misalnya pemberian jasa, atau berupa agen. Dalam kaitan ini, yang merupakan subjek pajak seharusnya orang atau badan yang memiliki atau yang menjalankan usaha di pabrik, gedung kantor, bengkel, perkebunan dan sebagainya atau yang melakukan pemberian jasa tersebut, bukan pabrik, gedung kantor, bengkel, perkebunan atau pemberian jasanya.

Seorang guru besar Hukum Pajak, Prof. Dr. Kees van Raad, mengibaratkan hubungan antara perusahaan dengan bentuk usaha tetap itu ibarat hubungan antara telur dan kuning telur. Bentuk usaha tetap diibaratkan sebagai kuning telur yaitu bagian dari telur kalau semua unsur-unsur dalam telur itu, yaitu kulit telur, kuning telur dan putih telur ada. Sebaliknya, kita tidak dapat mengatakan telur kalau hanya berupa kuning telur. Dengan mengambil perumpamaan di atas, bentuk usaha tetap itu tidak dapat dikatakan sebagi subjek pajak karena hanya merupakan bagian dari perusahaan yang dalam perumpamaan di atas berupa kuning telur bukan telur, sedangkan yang merupakan subjek pajak adalah perusahaannya, yang menurut perumpamaan di atas merupakan telurnya.

Alasan menjadikan bentuk usaha tetap sebagai subjek pajak adalah untuk menggantikan subjek pajak luar negeri yang mempunyai bentuk usaha tetap tersebut, agar memudahkan pengenaan pajak terhadap subjek pajak luar negeri yang bersangkutan. Dengan kata lain, dapat dikatakan bahwa bentuk usaha tetap adalah subjek pajak substitusi atau kadangkala di sebut sebagai subjek pajak palsu (pseudo tax subject).

BUT (Permanent Establishment) merupakan terminologi perpajakan internasional yang merupakan konsekuensi dari kegiatan usaha dengan basis/lokasi tetap di negara treaty partner setelah memenuhi kondisi-kondisi tertentu yang diatur dalam Tax Treaty atau Undang-undang seperti jenis kegiatan usaha yang dilaksanakan di negara treaty partner, sumber penghasilan dan jangka waktu (Time Test). Oleh karena itu, UU pajak tidak mengatur syarat-syarat pendirian BUT tetapi mengatur bagaimana dan kapan suatu bentuk usaha dianggap sebagai BUT dan ketentuan mengenai kegiatan 
usaha yang tidak dapat diklasifikasikan sebagai BUT. Dengan kata lain, suatu kegiatan usaha di negara treaty partner tidak secara otomatis menjadi BUT. Untuk adanya suatu bentuk usaha tetap diperlukan syarat-syarat sebagai berikut. Pertama, adanya tempat usaha (place of business). Kedua, usaha atau yang dilakukan haruslah bersifat permanen (syarat "certain degree of permanent”). Ketiga, adanya sifat ketergantungan (dependence).

Dengan mengambil salah satu contoh bentuk usaha tetap tersebut di atas, misalnya gedung kantor, gedung kantor tersebut baru akan merupakan bentuk usaha tetap apabila di gedung kantor itu dijalankan usaha (business) atau kegiatan suatu perusahaan luar negeri. Sebaliknya, apabila di gedung kantor tersebut tidak dijalankan usaha, misalnya apabila kegiatan di gedung kantor tersebut hanya pengumpulan data atau promosi untuk kepentingan suatu perusahaan di luar negeri, maka gedung kantor tersebut bukan bentuk usaha dari perusahaan luar negeri yang bersangkutan.

Dilihat dari bentuknya, bentuk usaha tetap dapat dikategorikan dalam empat tipe sebagai berikut. Pertama, bentuk usaha tetap tipe asset. Dalam tipe ini bentuk usaha tetap dapat berupa gedung kantor, bengkel, pabrik, tanah pertanian, peternakan, pertambangan dan penggalian sumber alam. Kedua, bentuk usaha tetap tipe aktifitas, misalnya dalam bentuk proyek konstruksi, proyek instalasi, dan pemberian jasa (furnishing of services). Ketiga, bentuk usaha tetap tipe agen. Dalam tipe ini bentuk usaha tetap berupa orang pribadi atau badan yang bertindak sebagai agen dari perusahaan luar negeri yang kedudukannya tidak bebas (dependent agent). Keempat, bentuk usaha tetap tipe asuransi. Dalam tipe ini bentuk usaha tetap dapat berupa agen atau pegawai dari perusahaan asuransi yang tidak didirikan dan tidak bertempat kedudukan di suatu negara yang menerima premi asuransi atau menanggung risiko di negara itu.

\section{Kesulitan Penentuan Bentuk Usaha Tetap untuk Usaha-usaha Tertentu}

Berikut ini penulis coba menampilkan masalah-masalah yang merupakan kesulitan dalam pengenaan pajak berkaitan dengan penentuan ada tidaknya bentuk usaha tetap di suatu negara khususnya di Indonesia. Contoh-contoh yang terkait adalah: Pertama, perlakuan PPh jika kabel dan pipa bawah laut tersebut menghubungkan dua atau lebih negara yang mempunyai P3B (Persetujuan Penghindaran Pajak Berganda) dengan Indonesia; penghasilan diperlakukan sebagai business income karena dianggap (sesuai definisi) sebagai bentuk usaha tetap, yang menjadi masalah adalah bagaimana menghitung laba usaha dari kegiatan tersebut sebagai dasar pengenaan pajak penghasilan. Perlu diketahui bahwa secara spesifik UU PPh tidak atau belum mengatur tentang masalah ini. Ada dua kemungkinan yang bisa dijadikan pertimbangan untuk mengenakan PPh atas kegiatan usaha itu, dengan menerapkan ketentuan seperti yang berlaku bagi usaha lain. Ini berarti wajib pajak BUT harus menghitung laba kena pajak sesuai dengan ketentuan pasal 5, 11, 17 dan 26 dari UU PPh. Masalah berikutnya adalah penyusutan atas fasilitas tersebut, yang menyangkut golongan harta dan dasar penyusutan.

Seandainya penggolongan harta untuk keperluan penyusutan sudah dapat dilakukan, kesulitan berikutnya adalah bagaimana menentukan dasar penyusutannya. Sesuai contoh kasus tadi, tidak seluruh fasilitas tersebut terletak di perairan internasional dan di perairan negara domisili. Dengan mempertimbangkan faktor tersebut di atas, maka yang paling masuk akal adalah dengan menerapkan secara proporsional nilai investasi untuk kabel atau pipa bawah laut di Indonesia. Sebagai alternatif dari cara menentukan besarnya pajak atas kegiatan usaha seperti diuraikan di atas, mungkin dapat diperlakukan analog seperti perpajakan atas perwakilan dagang asing, yaitu dengan menerapkan norma 1\% dari penjualan sebagaimana diatur dalam Kepmenkeu No. 634/KMK.04/1994.

Kedua, kabel atau pipa bawah laut tersebut berada di wilayah Indonesia milik perusahaan luar negeri sebagai operator. Kabel atau pipa bawah laut yang berada di wilayah Indonesia milik perusahaan luar negeri sebagai operator, maka fasilitas tersebut masuk dalam kategori "harta tetap". Indonesia mempunyai hak mengenakan pajak atas penghasilan dari harta tetap tersebut. 
Penghasilan dari harta tetap. Dalam hal kasus yang kedua, yaitu pemilik kabel atau pipa bawah laut bertindak sebagai operator yang menyewakan fasilitas yang dimilikinya, maka sebagaimana analisis terdahulu, penghasilan yang diperoleh dari kegiatan tersebut, dari sudut pandang P3B, masuk kategori penghasilan dari harta tetap.

Sesuai dengan ketentuan pasal 26 pembayaran untuk hak menggunakan harta dikenai $\mathrm{PPh}$ dengan tarif $20 \%$ dari harga sewa. Namun, masalah yang sama akan timbul dalam menentukan harga sewa sebagai dasar pengenaan pajak. Secara teori, dasar pengenaan pajak adalah secara proporsional panjang kabel atau pipa yang berada di perairan Indonesia, tetapi kalau kita mau kaji lebih jauh ternyata teori yang ada ini malah merugikan negara Indonesia, suatu misal perusahaan yang ada di Indonesia menggunakan fasilitas tersebut untuk mengalirkan migas, maka fasilitas yang dipergunakan membentang dari Indonesia sampai ke luar negeri, sementara hak pemajakan Indonesia atas penghasilan dari penggunaan harta tetap hanya terbatas pada harta yang terletak di Indonesia. Jadi, secara umum kesimpulannya definisi "bentuk usaha tetap" sebagaimana diatur di pasal 2 ayat (5) perlu disempurnakan sehingga keberadaan fasilitas di Indonesia akan menyebabkan timbulnya BUT.

Ketiga, penentuan bentuk usaha tetap perusahaan asuransi. Penentuan apakah perusahaan asuransi WPLN mempunyai BUT di Indonesia tidak hanya dengan tempat usaha atau keagenan, tetapi dapat juga karena penerimaan premi atau penutupan resiko di Indonesia melalui pegawai (atau agennya). Dengan demikian, nampak bahwa penerimaan premi atau penutupan risiko tanpa pegawainya atau agen tidak memenuhi kriteria BUT. Sebagaimana telah diketahui bersama bahwa pembayaran premi asuransi/reasuransi dari perusahaan asuransi di Indonesia (yang notabene sebenarnya hanya 'calo'-nya perusahaan asuransi asing) ke perusahaan asuransi di luar negeri (misalnya Jepang) bukan merupakan obyek PPh pasal 26.

Yang ingin saya tanyakan adalah, apa dasar pemikiran/pertimbangan pemerintah menerapkan aturan tersebut, jika pada akhirnya hampir seluruh omset dari premi asuransi di dalam negeri di reasuransi ke luar negeri, sementara perusahaan asuransi dalam negeri hanya memperoleh penghasilan dari selisih komisi. Sebetulnya secara umum kalau kita coba kaji hal ini maka akan nampak bahwa perusahaan asuransi di dalam negeri kita sebagai kepanjangan tangan dari Perusahaan Asuransi besar di Luar negeri untuk memperoleh penghasilan di Indonesia, dimana kriteria ini sebetulnya bisa dikategorikan sebagai Bentuk Usaha Tetap. Jadi, sebetulnya bisa dikenakan PPh pasal 26.

Keempat, penentuan bentuk usaha tetap dan pengenaan pajak terhadap transaksi $\boldsymbol{e}$-commerce. Hal yang lebih sulit lagi kalau kita melihat model transaksi yang menggunakan media komputer yang sering kita kenal sebagai Electronic Commerce, sebagaimana kita ketahui dalam dunia yang semakin berkembang yang ditandai dengan semakin majunya teknologi, maka mau tidak mau akan membawa pengaruh kepada semua tatanan sistem yang ada sekarang ini. Electronic commerce (e-commerce) yang merupakan salah satu dari bentuk kemajuan teknologi tersebut, tentu akan mempengaruhi sistem perdagangan yang ada selama ini. Walaupun kemunculan e-commerce masih baru, namun potensi yang dijanjikan dalam perdagangan e-commerce ini cukup cerah. Salah satu penelitian (Forrester Research) memprediksi bahwa total pembelanjaan dalam e-commerce yang dalam tahun 1996 kurang dari \$ 500 juta akan meningkat menjadi \$ 6,5 milyar dalam tahun 2000. Koran Media Indonesia edisi 9 Agustus 2001 melaporkan tentang hasil penelitian Gartner Dataquest yang memprediksikan pada tahun 2003 jumlah pelanggan internet (yang merupakan pangsa pasar e-commerce) di wilayah Asia Pasifik akan berjumlah sebesar 183,3 juta, Amerika sebesar 162,8 juta dan 162,2 juta di Eropa Barat. Apabila angka-angka tersebut dibandingkan dengan saat awal-awal digunakannya internet pada tahun 1988 sampai dengan tahun 1994 yang tumbuh dari nol sampai 3 juta pemakai internet, maka prediksi jumlah pemakai internet pada tahun 2003 tersebut sangat fantastik.

Dengan munculnya dan makin berkembangnya transaksi e-commerce tersebut, menimbulkan pertanyaan-pertanyaan sebagai berikut: bagaimana administrasi pajak mengantisipasi cara pemajakan (tax treatment) atas penghasilan dari transaksi e-commerce yang tidak mengenal batas geografis 
tersebut; dan apakah ketentuan perpajakan yang ada sekarang ini telah memadai atau belum cukup memadai untuk mengantisipasi penghasilan dari transaksi e-commerce.

Iwan Juniardi, Staf Ditjen Departemen Keuangan, mengatakan bahwa kesulitan penerapan PPh dan PPN bagi bisnis sistem informasi ini dikarenakan Ditjen Pajak tidak mempunyai akses terhadap data transaksi. "Kesulitan ini semakin meningkat bila dikaitkan dengan transaksi software yang memberi kemudahan bagi pembeli untuk men-download software langsung dari Internet," katanya kemarin di sini. Selain itu, ungkap Juniardi, penentuan suatu web server sebagai bentuk usaha tetap (BUT) atau tidak juga menimbulkan masalah mengingat batasan yang terjadi belum jelas. "Bila web server hanya menampilkan iklan atau informasi lain sehubungan dengan produk yang diperdagangkan maka tidak akan menimbulkan suatu BUT," ujarnya.

Namun demikian, lanjutnya, bila web server tersebut fully automated web server yang menjalankan fungsi penerimaan pesanan dan pembayaran serta pengiriman produk digital atau jasa, termasuk bila konsumen membeli dan sekaligus men-download software maka web server tersebut merupakan BUT. Juniardi menjelaskan Ditjen Pajak menyikapi permasalahan di atas dengan melakukan analisa yang terus-menerus terhadap e-commerce yang melibatkan sejumlah pihak terkait sehingga pelaksanaan peraturan perpajakan berjalan efektif. "Saat ini kami telah membentuk tim khusus untuk menangani permasalahan yang berkaitan dengan e-commerce," tuturnya. Namun demikian, lanjut Juniardi, peraturan yang akan ditetapkan nanti sebaiknya merupakan kesepakatan internasional. Dia mengungkapkan penghasilan bisnis sistem informasi termasuk bisnis software dan sistem integrasi di dalamnya yang diterima oleh pribadi atau badan, baik yang berkedudukan di Indonesia maupun di luar negeri, termasuk obyek PPh.

Jadi, yang menjadi pertanyaan, yaitu bagaimana pengenaan pajaknya berkaitan dengan transaksi online yang sekarang lebih dikenal dengan e-commerce karena banyak perusahaanperusahaan maya yang terdaftar diluar negeri tetapi perusahaan ini banyak memperoleh keuntungan dari negara Indonesia karena website dari perusahaan yang dimaksud bisa di akses di Inonesia. Karena secara umum proses transaksi seperti ini bisa menimbulkan bentuk usaha tetap di mana Indonesia berhak untuk mengenakan pajak kepada perusahaan yang bersangkutan.

\section{SIMPULAN}

Perlakuan bentuk usaha tetap sebagai badan hukum adalah tidak tepat, apalagi seperti yang kita ketahui, bayak sekali ketentuan-ketentuan hukum positif kita yang menganggap bahwa bentuk usah tetap ini sebagai suatu badan hukum ataupun badan usaha karena kreteria yang diminta tidak bisa dipenuhi sedikitpun, misalnya kekayaan yang dimiliki oleh perusahaan tetap itu pasti bukan sepenuhnya kekayaannya karena BUT ini hanya kepanjangan tangan dari perusahaan yang ada di luar negeri, untuk melakukan perbuatan hukum juga pasti tidak bisa karena yang melakukan perbuatan hukum pasti badan asing yang dimaksud. Pada dasarnya, bentuk usaha tetap ini harus diperlakukan sebagai suatu sarana untuk pengenaan pajak.

Untuk menentukan suatu bentuk usaha tetap di suatu negara sumber, ternyata tidak semudah apa yang tertulis di dalam udang-undang. Ada beberapa simpulan yang terkait dengan kondisi ini. Pertama, perlakuan PPh jika kabel dan pipa bawah laut tersebut menghubungkan dua atau lebih negara yang mempunyai P3B (Persetujuan Penghindaran Pajak Berganda) dengan Indonesia adalah sebagai business income karena dianggap (sesuai definisi) sebagai bentuk usaha tetap, yang menjadi masalah adalah bagaimana menghitung laba usaha dari kegiatan tersebut sebagai dasar pengenaan pajak penghasilan. Perlu diketahui bahwa secara spesifik UU PPh tidak atau belum mengatur tentang masalah ini. Kedua, kabel atau pipa bawah laut yang berada di wilayah Indonesia milik perusahaan 
luar negeri sebagai operator, maka fasilitas tersebut masuk dalam kategori "harta tetap". Indonesia mempunyai hak mengenakan pajak atas penghasilan hanya dari harta tetap tersebut. Jadi secara umum definisi "bentuk usaha tetap" sebagaimana diatur di pasal 2 ayat (5) perlu disempurnakan sehingga keberadaan fasilitas di Indonesia akan menyebabkan timbulnya BUT.

Ketiga, untuk usaha dibidang asuransi ini juga secara umum reasuransi diijinkan, praktek ini perlu kita kaji juga, karena secara umum pembayaran premi ke luar negeri ini di ijinkan dan tidak dikenakan pajak juga terkait dengan keuntungan dari perusahaan asuransi yang terkait, tapi lantas bagaimana kalau asuransi yang ada di Indonesia ini hanya dipakai sebagai perusahaan perantara dimana pihak Asuransi di luar negeri bisa secara leluasa memperoleh keuntungan yang besar. Kondisi seperti ini sebetulnya bisa kita masukkan dalam kriteria BUT. Jadi, perusahaan asuransi yang ada di Indonesia merupakan BUT-nya perusahaan luar yang dimaksud. Keempat, untuk perusahaanperusahaan maya, kecenderungan perdagangan lewat media internet dari tahun ke tahun cukup tinggi seperti yang kita ketahui banyak juga perusahaan-perusahaan yang sudah menggunakan tekhnologi ecommerce dalam transaksinya. Jadi intinya, jika terjadi perdagangan secara online dan yang memperoleh keuntungan perusahaan-perusahaan di luar negeri.. Selama ini memang agak sulit mendeteksi para pihak yang terkait dengan perdagangan ini. Tetapi pada dasarnya suatu Web Site yang fully aoutomatic di mana para pihak biaa melakukan transaksi secara online, baik itu berkaitan dengan pemesanan barang maupun pembelian ini sudah bisa kita kategorikan sebagai BUT dan tentunya kalau bisa dibuktikan, maka secara hukum bisa dikenakan pajak.

\section{DAFTAR PUSTAKA}

Ali, Chidir. (1987). Badan hukum, Bandung: Alumni.

Badrulzaman, M. D. (2001). ”E-commerce tinjauan dari hukum kontrak Indonesia”, Hukum Bisnis XII.

Fitriandi, P., et al. (2005). Kompilasi Undang-undang perpajakan terlengkap, susunan satu naskah, Jakarta: Salemba Empat.

Gade, M., dan Djamaludin. (1995). Hukum pajak, Jakarta: Lembaga Penerbit Fakultas Ekonomi, Universitas Indonesia.

Gunadi. (1999). Pajak internasional, Jakarta: Lembaga Penerbit Fakultas Ekonomi, Universitas Indonesia.

Keputusan Menteri Keuangan No. 628/KMK.04/1991 tanggal 26 Juni 1991 tentang Norma penghitungan khusus penghasilan neto bagi wajib pajak yang melakukan kegiatan usaha di bidang pengeboran minyak dan gas bumi serta angsuran pajak penghasilan dalam tahun berjalan oleh wajib pajak sendiri.

Makarim, E. (2003). Kompilasi hukum telematika, Jakarta: PT Raja Grafindo.

Peraturan Pemerintah No. 140 Tahun 2000 tentang Pembayaran pajak penghasilan atas penghasilan dari usaha jasa konstruksi.

Purbo , O. W. P., dan Aang A. W. (2001). Mengenal e-Commerce, Jakarta: PT Elex Media Komputindo. 
Rusli, H. (1996). Perseroan terbatas dan aspek hukumnya, Jakarta: Pustaka Sinar Harapan.

Rusli, H. (2001). Analisis kedudukan badan hukum dari firma, law review, Jakarta: Universitas Pelita Harapan.

Soemitro, R. (1982). Pajak dan pembangunan, cetakan kedua, Bandung: PT Eresco.

Soemitro, R. (1977). Hukum pajak internasional Indonesia, perkembangan dan pengaruhnya. Cetakan pertama, Bandung: PT Eresco.

Surachmat, R. (2000). Persetujuan penghindaran pajak berganda suatu pengantar, Jakarta: PT Gramedia.

Zakaria, J. (1998). Pajak penghasilan bentuk usaha tetap, Jakarta. 